\title{
PERCEPTION OF BORDER AREA LECTURERS AND STUDENTS REGARDING THE USE OF COMPUTER TECHNOLOGY AND SMARTPHONE APPLICATION IN LEARNING ENGLISH
}

\author{
Woro Kusmaryani \\ Faculty of Teacher Training and Education, Universitas Borneo Tarakan, Indonesia \\ Corresponding Author Email: lunasaski@gmail.com
}

\begin{tabular}{ll}
\hline \hline Article Info & Abstract \\
\hline Article History & This study aimed at exploring the use of computer technology and smartphone \\
Received: September 2021 & applications in the learning of English. The inquiry looked into the use of \\
Revised: October 2021 & educational technology to teach and learn English which was perceived by the \\
Published: October 2021 & lecturers and the students at English department of Universitas Borneo Tarakan. \\
\hline Keywords & A case study design using questionnaires and interview data was expected to \\
Computer Technology; & reveal lecturers and students' perceptions comprehensively. The data obtained \\
Smartphone Applications; $;$ & were analyzed with quantitative and qualitative data analysis in descriptive \\
English Language & statistics and coding. This study indicated that computer technology and \\
Learning; & smartphone applications in learning English could smoothly run if the internet \\
& networkwas stable and there was a sufficient data quota. In its use, both lecturers \\
& and students needed to coordinate well regarding the English learning platform \\
& used. Both lecturers and students needed to prepare, implement structured \\
& learning, and pay attention to learning evaluation. Content, pedagogy, and \\
& technology were crucial things to be considered when designing online courses.
\end{tabular}

How to cite: Kusmaryani, W. (2021). Perception of Border Area Lecturers and Students regarding the use of Computer Technology and Smartphone Application in Learning English, JOLLT Journal of Languages and Language Teaching, 9(4) pp. 496-503. DOI: https://doi.org/10.33394/jollt.v\%vi\%i.4268

\section{INTRODUCTION}

The need for various teaching techniques leads teachers to use technological tools to facilitate learning and serve their students' needs. Educational technology refers to the various materials used to enhance the learning process and make teaching enjoyable. In this case, it facilitates learning by using appropriate technological processes and resources. Educational technology is a field in which human learning is facilitated. This concerns the development, organization, and utilization of learning resources (Raja \& Nagasubramani, 2018). E-learning is a term related to Educational Technology; it uses technological equipment such as computers and digital technology (Asta, 2010). Technology satisfies learners' visual and auditory senses. Educational technology considers three aspects: student levels, teacher interests, and training, and institutional goals. Schools are linked to the Internet with this modern way of teaching. Also, activities such as video conferencing make it possible to bring the world to the classroom (Nomass, 2013).

Educational technology supports the Teaching of English by presenting real situations and contexts. Thus, technology materials such as computers, language labs, and audio-visual aids are useful for teaching and learning English. Technology helps teachers in teaching. Besides, its use can make students more motivated (Nomass, 2013). The use of technological tools is an essential instrument in teaching and learning English. Technology makes learning exciting and teaching more productive. Educational technology can be used as a creative tool. It can have several instruments that make it more productive to teach and learn (Solanki \& Phil, 2012). 
The influence of technology on the teaching and learning of English has had many positive effects. Using technology tools in the learning process creates better communication for students. For example, students do not need to go to a country where the target language is used as the mother tongue with the World Wide Web. The use of multimedia provides an authentic situation; this can help students to practice the language. This communication is suitable for students who are too shy to speak (Rodinadze \& Zarbazoia, 2012).

The use of technology in the classroom can provide benefits for teachers and students. Technology will provide students with various activities to learn more about the target language and practice it (Solanki \& Phil, 2012). This means more comprehensive access to information and increased skills. Learners can learn even without the help of using the Internet. Knowledge in operating computers will be constructive for students to have responsibility for their learning. Besides, students can search for answers needed to do their homework. Using technology can bring ease in study. This can promote an exciting way to learn because many pictures and graphics can provide computers. With technology, the teaching process has been improved. This has transformed the education system from a teacher-centered teaching method to a student-centered model of learning. Students are passive recipients of information; they take part in the learning process a little. Teaching English creates a student-centered learning environment that develops students' critical thinking skills and problem-solving abilities (Rodinadze \& Zarbazoia, 2012).

Three research questions focused on researchers investigating lecturers and students in the Department of English Language Education, Faculty of Education and Training (FKIP), Universitas Borneo Tarakan.

1. What technology tools do lecturers and students use in learning English?

2. What are the consequences of using educational technology, and if traditional teaching methods are still used or not?

3. What are lecturers' and students' perspectives regarding the use of educational technology for teaching and learning English in the English Education Department of the University of Borneo Tarakan?

\section{RESEARCH METHOD \\ Research Design}

The design of this research was a case study (Creswell, 2012), which took place in the department of English education, Faculty of Teacher Training and Education, University of Borneo Tarakan which is the only state university in the province of North Kalimantan which is also close to the Malaysian border. The subjects of this research were the lecturers and the students in the English department, Faculty of Teacher Training and Education, Universitas Borneo Tarakan. By using purposive sampling, considering the objectivity of the views and reactions of research subjects regarding the use of computer technology and smartphone applications in learning English so that the subjects of this study consisted of 2 lecturers (different areas of expertise) and 3 classes with different semesters.

\section{Data Collection Technique Questionnaire}

In this research used closed questions, multiple choice questions and open questions. Closed questions limited the respondent to a limited set of answers which are often (yes) or (no). Multiple choice questions provided multiple answers from which respondents have to choose the one that suits them best. Open-ended questions gave respondents the opportunity to answer freely without limits. The questions given were questions related to the use of computer technology and smartphone applications in learning English. 


\section{Interview}

In this research, the researcher relied on the use of structured interviews because this type was especially helpful when the researcher was aware of what was not known and was therefore in a position to structure questions that supplied the necessary knowledge. The rationale behind this interview was to collect data on the current status and ideas about the use of technology by lecturers in the English department at Universitas Borneo Tarakan.

\section{Data Analysis Technique}

Quantitative Data Analysis

Quantitative data analysis was used to generalize the results from the sample population. Quantitative analysis in this research was intended to explain phenomena by collecting numerical data which was analyzed using mathematical-based methods and in this research was in the form of descriptive statistics. It was a kind of measuring people's thinking in the form of a statistical point of view from the questionnaire data obtained.

\section{Qualitative Data Analysis}

In contrast to quantitative methods which focused on measurement, qualitative methods were used to describe human behavior. With the form and pattern of antecedent-consequence forms, where the data obtained from the interviews in the form of words in spoken mode were transcribed with the aim of understanding people's thoughts and feelings and why they made certain choices.

\section{RESEARCH FINDINGS AND DISCUSSION Research Findings}

This study aimed to provide data that can help improve educational technology for teaching and learning English. This study attempted to demonstrate educational technology's role by providing a broader view of students' and lecturers' reactions to its use. This study aimed to find the technological tools used by lecturers and students in learning English. This research also tried to show the consequences of using educational technology and if traditional teaching methods were still used or not. This research aimed to gather various perspectives from lecturers and students regarding educational technology for teaching and learn English in the University of Borneo Tarakan's English language education department. The results obtained from this study will be presented from student side and the lecturer side.

One hundred fifty-four students participated in this survey. Students' views on online learning show that some students have a favorable view of technology use. They responded well and very useful for some students who view that the ineffective use of technology in the learning process is too complicated in using online learning platforms and prefers to use lightweight technology such as WhatsApp.

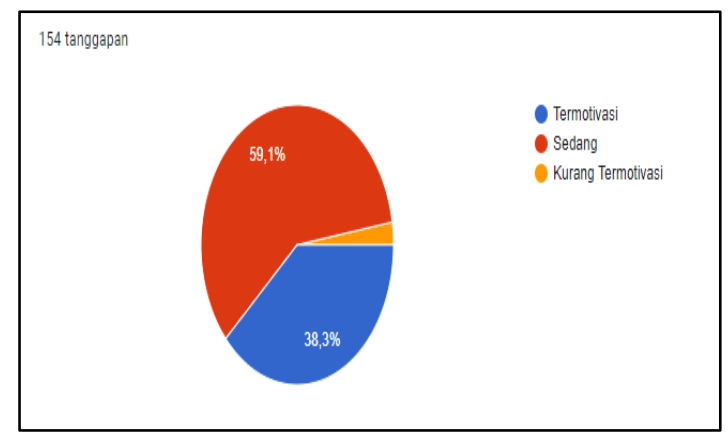

Diagram 1. Motivation during Technology Use 
The diagram above shows that $59.1 \%$ of students responded that their motivation for using technology was moderate. $38.3 \%$ of students said they were very motivated by technology, while the remaining $2.6 \%$ of students were less motivated by technology use.

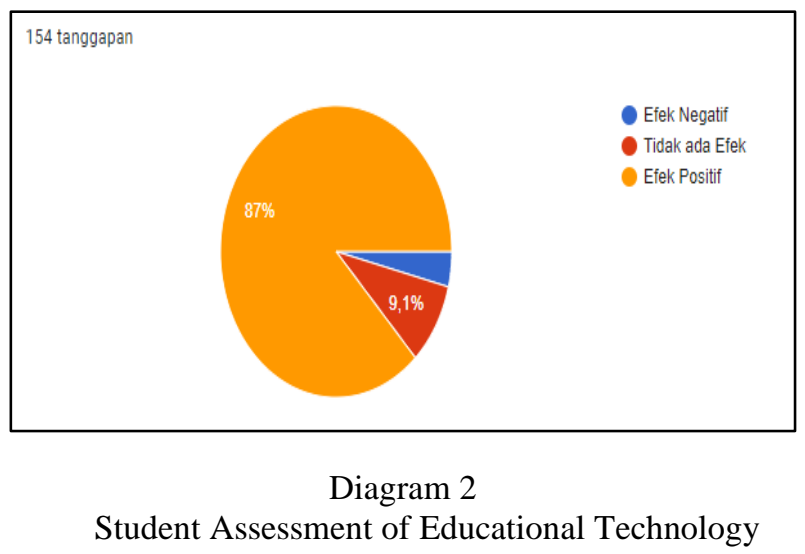

The diagram above shows that $87 \%$ of students expressed a positive effect on their educational technology assessment. As many as $9.1 \%$ of students stated that there was no effect on the use of educational technology, and the remaining $3.9 \%$ rated the negative effect on educational technology.

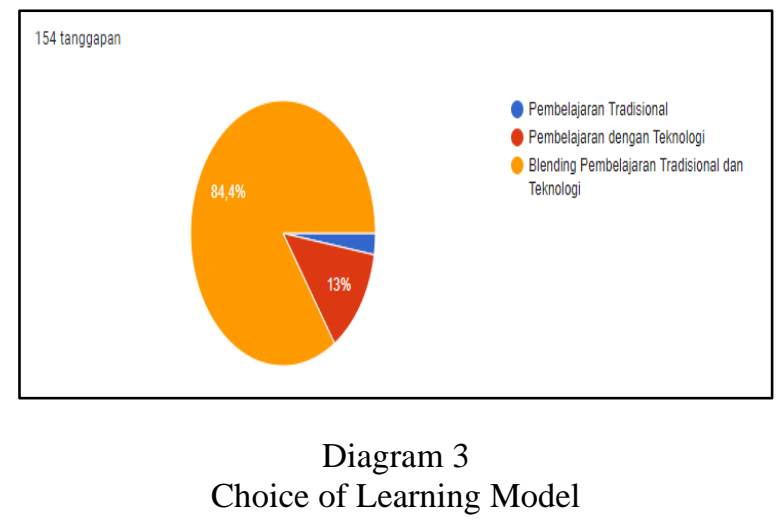

The diagram above shows 84.4 students choosing the traditional and technological blending model of learning. $13 \%$ of students choose learning models with technology, and the remaining $2.6 \%$ choose traditional learning models.

\section{Discussion}

The change in their face-to-face learning habits to online learning made them confused and found it challenging to understand the lecturer's material. Although online learning did not waste more energy going to campus, it costed money to purchase the internet quota. According to them, online learning would run smoothly if all students had a stable internet connection. Some other technical matters were the rotating power outages that affect students' smartphones and laptops' battery power. The unstable internet network made it difficult for students to catch up with synchronous explanations through zoom meetings or Google meetings. Student motivation to learn had also decreased so that some students became less responsive during the online learning process. Students admitted that they lack concentration in learning, and they also complained of sore eyes if they were too long in front of a laptop or staring at their smartphone screen. Students' understanding of lecture material also decreased during online learning compared to face-to-face learning. According to them, some lecturers were not optimal in delivering lecture material, and there were misunderstandings in receiving the information 
obtained. Although online learning helped students find information from Google and YouTube, if the internet network were inadequate, especially for students in rural areas, online learning would be difficult for students.

The readiness of learners to take online courses is one of the main issues discussed in the literature (Hung et al., 2010). Not all students successfully participated in online courses. Identifying and adopting the learning styles and skills needed to participate in online courses can be challenging for learners (Luyt, 2013). Most learners needed to be self-motivated and self-directed. Online instructors must be ready to assist students who lack the required study skills. The main aspects or dimensions of readiness to help students must be further clarified. Literature shows that students' technical skills were related to computers and the Internet (Peng et al., 2006). Their perceptions and attitudes towards the Internet (Tsai \& Lin, 2004), their cultural and non-English backgrounds (Luyt, 2013), and their time management skills (Roper, 2007) were considered necessary for shaping learners' readiness to participate in online courses.

Interviews were conducted with two lecturers in the English education department, with one lecturer with an English education background and one lecturer with a linguistic background. Regarding the importance of technology in learning, the two lecturers stated that it was crucial to use technology to teach and learn English. They claimed that the use of technology helps them both in-class teaching and its use outside the classroom. They were quite confident when using technology in class with students for several reasons. They provided insights into using technology for English language teaching as beneficial to students more than traditional teaching. They also pointed to the problems faced by students in terms of technology use. Regarding adopting new educational technology that could free lecturers from the heavy workload, the two lecturers had their disagreement. Regarding relying too much on educational technology that could replace lecturers, they disagreed with this and said that technology could not change lecturers' traditional roles.

One of the main challenges with online education is its changing role (Syverson \& Slatin, 2010). Four distinct roles were identified for online instructors: pedagogical, social, managerial, and technical (Berge, 1998). Pedagogical role refers to teaching methods; the social role is the instructor's way of establishing social relationships with students; managerial roles include administrative and organizational tasks, and technical responsibility is the technical support that instructors provide to students. Online teaching education objectives are achieved predominantly by the execution of pedagogical tasks (Robertson, 2000).

Other literature supports a shift in the instructor role, emphasizing the ability to deliver content, transfer from teacher-centered education to students, better communication, and use technology (Juan et al., 2011). The shift from faculty-centered education (faculty lectures) to a more student-centered approach (students decide how they want to learn) resulted in the instructor's role as a facilitator. The role of the faculty changed from a face-to-face "player" in the delivery of lecture-style information to a "guide" who had to make adjustments to content delivery based on their online environment (Coppola et al., 2001). In other words, from an information transfer agent to a professional, the role of the online teacher has changed to direct the student learning process (Juan et al., 2011). In this role, the instructor facilitates student learning rather than teaching students (lead lecture). Besides, faculty are available to provide input pedagogically, point to managerial or administrative instruments, and promote student interaction (Yang \& Cornelius, 2004).

The instructor may be responsible for preparing and planning material for the online course. The task of producing new material or adapting material from face-to-face classrooms to online settings can be very challenging ( $\mathrm{Li} \&$ Irby, 2008). Often appropriate training and support have not been provided to instructors who transition course content from face-to-face to online settings (Kyei-Blankson \& Keengwe, 2011). 
Content cannot merely be copied from face-to-face to online settings. Koehler, Mishra, Hershey, and Peruski (2004) encourage instructors to consider content, pedagogy, and technology when designing courses online. However, teachers may not be willing to change their teaching strategy when switching from face-to-face courses to online courses (Barrett, 2010). Apart from a lack of training and support, instructors also feel a lack of incentives to design and deliver online courses (Allen \& Seaman, 2010). Offering the right incentives increases instructors' willingness to design and deliver online courses (Hoyt \& Oviatt, 2013). However, institutions must consult with teachers to decide what rewards are given because they do not generally want extrinsic monetary incentives (Herman, 2013). Intrinsic motivators that can positively influence instructors to deliver online courses are flexible schedules and selfgratification. Other extrinsic motivators that may be more influential than monetary incentives include reducing workload and release time (Parker, 2003).

Students can learn content through flexible paths that can be changed for individual requirements through three fundamental principles: various means of representation, different means of engagement, and numerous means of expression. To proactively fulfill students' needs and learning preferences, representation employs a variety of tactics, methods, and tools that offer class information and content in various formats. Students can demonstrate their understanding in a variety of ways through expression and action. Students are encouraged to employ self-reflection and self-monitoring, and engagement looks at tactics like allowing student choice to boost their degree of active learning (Baldwin \& Ching, 2021).

Online education has the potential to change lives. It goes beyond the use of technology, triggering a shift in pedagogical paradigms that results in changes in teaching methods and learning behaviors, made possible by infrastructure and managerial decisions. To reduce transactional distance, engaging them and providing possibilities for interactivity and collaboration necessitates micro-level thoughts on course design and macro-level shifts in pedagogical assumptions. This is yet another evidence of the system's interconnection and dynamic connections between these components at various levels. Exploring this feature of online learning could bring valuable insights into the practice of online education. Moves to online education would be difficult and unsuccessful without changes at the macro level (Tamim, 2020).

Instructors are crucial in the development and implementation of online cross-cultural teaching. To ensure a meaningful and valuable online cross-cultural educational experience, instructional design and facilitation tactics are crucial. Designing teaching and learning activities, as well as selecting and using online technologies to enhance online cross-cultural learning, are two components of cross-cultural pedagogy in general. It is critical to give students with authentic opportunities to connect with people from various cultural backgrounds in order to improve intercultural learning. There are five components of supporting cross-cultural projects that deserve special attention: organization, content, training, introducing technical tools, and monitoring the process. Different affordances of online technology, learning goals, and the structure of assignments should all be considered when selecting digital tools (Deng et al., 2021).

\section{CONCLUSION}

Moving programs online is an opportunity to rethink the program. Any good transition to an online format will involve teamwork. Pairing a content expert with an instructional designer will do wonders for this program. Simple steps, such as starting with program objectives and thinking about how those objectives can be measured, will yield large program quality gains. The core of every well-thought-out online module, course, or program is to switch from "covered content" to an approach that maximizes learning. 
Another advantage of finding opportunities to move face-to-face campus programs online is increased institutional capacity. As digital platforms increasingly mediate education, the ability to use technology effectively and appropriately for teaching is recognized as a core institutional competency. However, learning how to blend and reverse residential courses effectively is not an institutional skill that can be developed overnight. Online programs are excellent opportunities to develop R\&D around learning innovations, but their development requires a significant resource commitment and a deliberate and focused approach.

\section{ACKNOWLEDGEMENT}

This research was funded by DIPA/PNBP, Research Center and Community Service (LPPM) Universitas Borneo Tarakan. This research was also supported by the English education department, Universitas Borneo Tarakan. The researcher would like to thank the lecturers and all the students who participated in this research.

\section{REFERENCES}

Allen, I. E., \& Seaman, J. (2010). Learning on demand: Online education in the United States. Sloan Consortium.

Asta, K. (2010). Impact of Modern Educational Technologies on Learning Outcomes: Application for E-learning in Biomedical Engineering. University of Tempere.

Baldwin, S. J., \& Ching, Y. H. (2021). Accessibility in Online Courses: a Review of National and Statewide Evaluation Instruments. TechTrends, 65(5), 731-742. https://doi.org/10.1007/s11528-021-00624-6

Barrett, B. (2010). Virtual teaching and strategies: Transitioning from teaching traditional classes to online classes. Contemporary Issues in Education Research, 3, 17-20.

Berge, Z. L. (1998). Barriers to online teaching in post-secondary institutions: Can policy changes fix it? Online Journal of Distance Learning Administration, 1, 1-12.

Coppola, N. W., Hiltz, S. R., \& Rotter, N. (2001). Becoming a virtual professor: Pedagogical roles and ALN. system sciences. The 34th Annual Hawaii International Conference.

Deng, L., Shen, Y. W., \& Chan, J. W. W. (2021). Supporting Cross-Cultural Pedagogy with Online Tools: Pedagogical Design and Student Perceptions. TechTrends, 65(5), 760-770. https://doi.org/10.1007/s11528-021-00633-5

Herman, J. H. (2013). Faculty incentives for online course design, delivery, and professional development. Innovative Higher Education, 38, 397-410.

Hoyt, J. E., \& Oviatt, D. (2013). Governance, faculty incentives, and course ownership in online education at doctorate-granting universities. American Journal of Distance Education, 27, 165-178.

Hung, M., Chou, C., Chen, C., \& Own, Z. (2010). Learner readiness for online learning: Scale development and student perceptions. Computers \& Education, 55, 1080-1090.

Juan, A. A., Steegman, C., Huertas, A., Martinez, M. J., \& Simosa, J. (2011). Teaching mathematics online in the European area of higher education: An instructor's point of view. International Journal of Mathematical Education in Science and Technology, 42, 141-153.

Koehler, M. J., Mishra, P., Hershey, K., \& Peruski, L. (2004). With a little help from your students: A new model for faculty development and online course design. Journal of Technology and Teacher Education, 12, 25-55.

Kyei-Blankson, L., \& Keengwe, J. (2011). Faculty-faculty interactions in online learning environments. International Journal of Information and Communication Technology Education, 7, 25-33.

Li, C., \& Irby, B. (2008). An overview of online education: Attractiveness, benefits, challenges, 
concerns, and recommendations. College Student Journal, 42(A), 449-458.

Luyt, I. (2013). Cross-cultural perspectives on promoting positive online learning experiences. Journal of Educational Technology Systems, 42, 3-20.

Nomass, B. B. (2013). The impact of using technology in teaching English as a second language. Academic Journal: English Language and Literature Studies, 3(1), 111-116.

Parker, A. (2003). Motivation and incentives for distance faculty. Online Journal of Distance Learning Administration, 6.

Peng, H., Tsai, C. C., \& Wu, Y. T. (2006). University students' self -efficacy and their attitudes toward the internet: The role of students' perceptions of the internet. Educational Studies, $32,73-86$.

Raja, R., \& Nagasubramani, P. C. (2018). Impact of modern technology in education. Journal of Appied and Advanced Research, 3(1).

Robertson, D. A. (2000). Teaching and Learning in Computer-mediated Conferencing Context. The University of Toronto.

Rodinadze, S., \& Zarbazoia, K. (2012). The advantages of information technology in teaching English language. Frontiers of Language and Teaching, 3, 271-275.

Roper, A. R. (2007). How students develop online learning skills. Educause Quarterly, 30, 6264.

Solanki, D. S., \& Phil, M. (2012). Use of technology in English language teaching and learning: An analysis. IPEDR, 33.

Syverson, M. A., \& Slatin, J. (2010). Evaluating learning in a virtual environment. Learning Record.

Tamim, S. R. (2020). Analyzing the Complexities of Online Education Systems: A Systems Thinking Perspective. TechTrends, 64(5), 740-750. https://doi.org/10.1007/s11528-02000538-9

Tsai, C. C., \& Lin, C. C. (2004). Taiwanese adolescents' perceptions and attitudes regarding the internet: Exploring gender differences. Adolescence, 39, 725-734.

Yang, Y., \& Cornelius, L. F. (2004). Students' perceptions toward the quality of online education: A qualitative approach. The Association for Educational Communications and Technology Conference. 